Uniwersytet Mikołaja Kopernika w Toruniu

Katedra Logistyki

Iwona Sobczak

\title{
PRZEDSIĘBIORSTWA Z KAPITAŁEM ZAGRANICZNYM NA TLE PRZEDSIĘBIORSTW BEZ KAPITAŁU ZAGRANICZNEGO W WOJEWÓDZTWIE KUJAWSKO-POMORSKIM
}

Z a ry s tre ś c i. W artykule podjęto próbę zabrania głosu w dyskusji na temat oceny znaczenia kapitału zagranicznego dla gospodarki województwa kujawsko-pomorskiego poprzez przedstawienie przedsiębiorstw z kapitałem zagranicznym na tle przedsiębiorstw wyłącznie z polskim kapitałem. Celem opracowania jest porównanie przedsiębiorstw z kapitałem zagranicznym z przedsiębiorstwami bez kapitału zagranicznego z województwa kujawsko-pomorskiego pod względem: zasobów kapitałowych, zatrudnienia, nakładów inwestycyjnych oraz osiąganych wyników finansowych.

S ło w a kluc z o we : aspekty regionalne, województwo kujawsko-pomorskie, przedsiębiorstwa z kapitałem zagranicznym, zasoby kapitałowe, zatrudnienie, nakłady inwestycyjne, wyniki finansowe.

\section{WSTĘP}

Przedsiębiorstwa z kapitałem zagranicznym stanowią dla regionalnej gospodarki nie tylko potencjał nowych miejsc pracy czy napływu kapitału zagranicznego, ale również inwestycje, z którymi mogą się wiązać innowacyjne technologie, know how, nowe systemy i metody zarządzania, nowatorskie rozwiązania techniczno-organizacyjne, wiedza i umiejętności. Ich wprowadzenie może przyczynić się do zmniejszenia „luki inwestycyjnej”, modernizacji regionalnej gospodarki oraz poprawy konkurencyjności. Władzom województwa szczególnie powinno zależeć na inwestycjach wysokotechnologicznych i wysokoinnowacyjnych, gdyż te sprzyjają rozwojowi polskiej przedsiębiorczości opartej na wiedzy i innowacjach. 
Przedstawienie przedsiębiorstw z kapitałem zagranicznym na tle przedsiębiorstw wyłącznie z polskim kapitałem jest ważne z punktu widzenia oceny znaczenia kapitału zagranicznego dla gospodarki województwa kujawsko-pomorskiego. Celem niniejszego opracowania jest porównanie przedsiębiorstw z kapitałem zagranicznym z przedsiębiorstwami bez kapitału zagranicznego z województwa kujawsko-pomorskiego pod względem: zasobów kapitałowych, zatrudnienia, nakładów inwestycyjnych oraz osiaganych wyników finansowych.

W prowadzonych rozważaniach pominięto podmioty zatrudniające do 9 osób, ze względu na specyfikę danych prezentowanych w opracowaniu GUS, Bilansowe wyniki fi nansowe podmiotów gospodarczych, które jest sporządzane na podstawie sprawozdań wypełnianych przez podmioty prowadzące księgi rachunkowe lub podatkową księgę przychodów i rozchodów, w których liczba pracujących wynosi 10 i więcej osób. Co prawda, udział mikroprzedsiębiorstw (podmiotów o liczbie pracujących do 9 osób) w ogólnej liczbie przedsiębiorstw z udziałem kapitału zagranicznego w województwie kujawsko-pomorskim był znaczący, na koniec 2007 roku stanowił 49\%. Dla porównania udziały pozostałych grup przedsiębiorstw wynosiły: małych 24\% (podmiotów o liczbie pracujących od 10 do 49), średnich 18\% (podmiotów o liczbie pracujących od 50 do 249) i dużych 9\% (podmiotów o liczbie pracujących 250 i więcej osób). Jednak analiza danych liczbowych z lat 1999-2007 wskazuje, iż dla gospodarki województwa kujawsko-pomorskiego zarówno pod względem osiąganych wyników finansowych, jak i ponoszonych wydatków inwestycyjnych, wartości zaangażowanego kapitału podstawowego i liczby zatrudnionych pracowników największe znaczenie spośród przedsiębiorstw z kapitałem zagranicznym miały przedsiębiorstwa zatrudniające od 10 osób. To właśnie te przedsiębiorstwa na koniec 2007 roku spośród wszystkich przedsiębiorstw z udziałem kapitału zagranicznego w województwie kujawsko-pomorskim skupiały 95\% kapitału podstawowego, zatrudniały 98\% osób pracujących w spółkach z kapitałem zagranicznym, ich udział w wydatkach ogółem na pozyskanie aktywów trwałych wynosił 90\%, udział w przychodach z całokształtu działalności ogółem osiagał 98\%, a udział w wyniku finansowym netto ogółem dochodził do 95\% (GUS, 2008a). Wynika $\mathrm{z}$ tego, iż pominięcie mikroprzedsiębiorstw w prowadzonych rozważaniach nie będzie miało istotnego wpływu na wnioski końcowe.

\section{ZASOBY KAPITAŁOWE PRZEDSIĘBIORSTW W WOJEWÓDZTWIE KUJAWSKO-POMORSKIM}

Kapitał podstawowy stanowi „rzeczywisty wkład właściciela lub współwłaściciela, wniesiony na uruchomienie jednostki gospodarczej z chwilą jej założenia, ewentualnie później podwyższony” (GUS, 2007a). Kapitał podstawowy 
obejmuje kapitał krajowy i kapitał zagraniczny, a także kapitał rozproszony, którego nie można przyporządkować konkretnym udziałowcom.

W województwie kujawsko-pomorskim kapitał podstawowy podmiotów z udziałem kapitału zagranicznego na koniec 2007 roku wynosił 2322,0 miliony zł. W strukturze tego kapitału kapitał zagraniczny stanowił 83\%, krajowy $13 \%$, a rozproszony $4 \%$. Wartość kapitału podstawowego przedsiębiorstw z udziałem kapitału zagranicznego w województwie kujawsko-pomorskim charakteryzowała się stałym wzrostem, począwszy od 1999 roku, w którym wynosiła 741,9 milionów zł, a skończywszy na roku 2007, w którym wynosiła 2322,0 miliony zł. Analizując strukturę kapitału podstawowego, można zauważyć, iż na systematycznie zwiększającą się wartość tego kapitału składał się stały wzrost zarówno kapitału krajowego, jak i zagranicznego. Udział kapitału zagranicznego w strukturze kapitału podstawowego do roku 2000 wzrastał do 87\%, a następnie od roku 2001 spadał, przyjmując najniższy stan 78\% w 2003 roku, by ustabilizować się na poziomie 80\% w latach 2004-2006 i osiągnąć poziom 83\% w 2007 roku (GUS, 2000a-2008a). Dane prezentujące liczbę podmiotów i wartość kapitału podstawowego przedstawiono w tabeli $1^{1}$.

Przedsiębiorstwa wyłącznie z polskim kapitałem stanowiły znaczącą większość przedsiębiorstw w województwie kujawsko-pomorskim. Na koniec 2007 roku udział przedsiębiorstw z kapitałem zagranicznym o liczbie pracujących 10 i więcej osób w ogóle przedsiębiorstw o liczbie pracujących 10 i więcej osób w województwie kujawsko-pomorskim wynosił 10\%. W związku z tym przedsiębiorstwa bez kapitału zagranicznego dominowały pod względem udziału w kapitale podstawowym ogółu przedsiębiorstw w województwie kujawsko-pomorskim, który na koniec 2007 roku wynosił 80\%. Dla lat 1999-2007 średnia kapitału podstawowego przedsiębiorstw wyłącznie z polskim kapitałem wynosiła 8354 mln zł, a adekwatnych przedsiębiorstw z kapitałem zagranicznym $1277 \mathrm{mln}$ zł.

Na korzyść przedsiębiorstw z kapitałem zagranicznym prezentowały się dane ukazujące wartość kapitału podstawowego w przeliczeniu na jedno przedsiębiorstwo lub jednego zatrudnionego. Na podstawie danych zaprezentowanych w tabeli 1 można stwierdzić, iż średnio na jedną spółkę z kapitałem zagranicznym w 2007 roku przypadało 8,8 miliona zł (w 2006 roku 7,7 miliona zł). W przypadku spółek wyłącznie z polskim kapitałem średnia wynosiła odpowiednio w 2007 roku 4,0 miliona zł, a w 2006 roku 4,3 miliona zł. Na jedną spółkę ogółem przypadało

1 Porównania przedsiębiorstw z kapitałem zagranicznym i przedsiębiorstw wyłącznie z polskim kapitałem w latach 2002-2003 pod względem liczby podmiotów, pracujących, kapitału podstawowego, przychodów ze sprzedaży i nakładów inwestycyjnych dokonano również w: Studzińska, Szóstek, 2005, s. 76-79. 
Tabela 1. Kapitał podstawowy $\mathrm{w}$ przedsiębiorstwach $\mathrm{z}$ kapitałem zagranicznym i w przedsiębiorstwach bez kapitału zagranicznego w województwie kujawsko-pomorskim (lata 1999-2007, podmioty o liczbie pracujących 10 i więcej osób)

\begin{tabular}{ccccccccccc}
\hline \multirow{2}{*}{ Przedsiębiorstwa } & 1999 & 2000 & 2001 & 2002 & 2003 & 2004 & 2005 & 2006 & 2007 \\
\cline { 2 - 10 } & \multicolumn{8}{c}{ Liczba przedsiębiorstw } \\
\hline Z kapitałem zagranicznym & 198 & 211 & 210 & 213 & 213 & 221 & 240 & 245 & 264 \\
Bez kapitału zagranicznego & b.d. & b.d. & b.d. & 2126 & 2206 & 2157 & 2169 & 2210 & 2335 \\
Ogółem & b.d. & b.d. & b.d. & 2339 & 2419 & 2378 & 2409 & 2455 & 2599 \\
\hline & \multicolumn{7}{c}{ Wartość kapitału podstawowego (w mln zł) } \\
\hline Z kapitałem zagranicznym & 504 & 683 & 819 & 965 & 1146 & 1425 & 1747 & 1886 & 2322 \\
Bez kapitału zagranicznego & 6397 & 6379 & 6639 & 8680 & 9222 & 9304 & 9543 & 9574 & 9449 \\
Ogółem & 6901 & 7061 & 7457 & 9645 & 10368 & 10729 & 11 290 & 11460 & 11771 \\
\hline & Kapitał podstawowy przypadający na jedno przedsiębiorstwo (w mln zł) \\
\hline Z kapitałem zagranicznym & 2,5 & 3,2 & 3,9 & 4,5 & 5,4 & 6,4 & 7,3 & 7,7 & 8,8 \\
Bez kapitału zagranicznego & - & - & - & 4,1 & 4,2 & 4,3 & 4,4 & 4,3 & 4,0 \\
Ogółem & - & - & - & 4,1 & 4,3 & 4,5 & 4,7 & 4,7 & 4,5 \\
\hline & Kapitał podstawowy przypadający na jednego zatrudnionego (w tys. zł) \\
\hline Z kapitałem zagranicznym & 18,4 & 24,0 & 28,4 & 32,5 & 42,2 & 46,7 & 56,4 & 56,2 & 58,3 \\
Bez kapitału zagranicznego & - & - & - & 51,9 & 53,4 & 54,7 & 57,0 & 54,4 & 52,3 \\
Ogółem & - & - & - & 49,0 & 51,9 & 53,5 & 56,9 & 54,7 & 53,4 \\
\hline
\end{tabular}

b.d. - brak danych

Źródło: opracowanie własne na podst.: GUS (od 2000a do 2008a) oraz GUS (od 2000b do 2008b).

w latach 2007 4,5 i 2006 4,7 miliona zł. W przypadku kapitału podstawowego przypadającego na jednego zatrudnionego w analizowanych podmiotach do 2005 roku widoczna była przewaga spółek z polskim kapitałem nad spółkami z kapitałem zagranicznym. Od 2006 roku zależność ta uległa zmianie. W 2007 roku na jednego zatrudnionego w przedsiębiorstwach z kapitałem zagranicznym przypadało 58,3 tys. kapitału podstawowego, a o 6 tys. kapitału podstawowego mniej na jednego zatrudnionego w przedsiębiorstwach z wyłącznie polskim kapitałem.

\section{ZATRUDNIENIE W PRZEDSIĘBIORSTWACH W WOJEWÓDZTWIE KUJAWSKO-POMORSKIM}

Na koniec 2007 roku w województwie kujawsko-pomorskim pracowało 697505 osób na 1334 274 osoby (mężczyzn i kobiet w wieku produkcyjnym) (US w Bydgoszczy, 2008). W spółkach z udziałem kapitału zagranicznego zatrudnionych było 40595 osób, co stanowiło 5,82\% ogółu pracujących 
Tabela 2. Pracujący w przedsiębiorstwach z kapitałem zagranicznym i w przedsiębiorstwach bez kapitału zagranicznego w województwie kujawsko-pomorskim (lata 1999-2007, podmioty o liczbie pracujących 10 i więcej osób)

\begin{tabular}{|c|c|c|c|c|c|c|c|c|c|}
\hline \multirow{3}{*}{ Przedsiębiorstwa } & \multicolumn{9}{|c|}{ Lata } \\
\hline & 1999 & 2000 & 2001 & 2002 & 2003 & 2004 & 2005 & 2006 & 2007 \\
\hline & \multicolumn{9}{|c|}{ Liczba pracujących (w tys.) } \\
\hline Z kapitałem zagranicznym & 27,4 & 28,4 & 28,8 & 29,7 & 27,2 & 30,5 & 31,0 & 33,5 & 39,8 \\
\hline Bez kapitału zagranicznego & b.d. & b.d. & b.d. & 167,2 & 172,6 & 170,1 & 167,3 & 176,0 & 180,5 \\
\hline \multirow[t]{2}{*}{ Ogółem } & b.d. & b.d. & b.d. & 196,9 & 199,8 & 200,6 & 198,3 & 209,5 & 220,4 \\
\hline & \multicolumn{9}{|c|}{ Udział w zatrudnieniu ogółem (w \%) } \\
\hline Z kapitałem zagranicznym & - & - & - & 15,1 & 13,6 & 15,2 & 15,6 & 16,0 & 18,1 \\
\hline \multirow[t]{2}{*}{ Bez kapitału zagranicznego } & - & - & - & 84,9 & 86,4 & 84,8 & 84,4 & 84,0 & 81,9 \\
\hline & \multicolumn{9}{|c|}{ Liczba pracujących przypadająca na jedno przedsiębiorstwo } \\
\hline Z kapitałem zagranicznym & 138,6 & 134,7 & 137,4 & 139,6 & 127,6 & 138,1 & 129,1 & 136,9 & 150,9 \\
\hline Bez kapitału zagranicznego & - & - & - & 78,6 & 78,2 & 78,9 & 77,1 & 79,6 & 77,3 \\
\hline Ogółem & - & - & - & 84,2 & 82,6 & 84,4 & 82,3 & 85,3 & 84,8 \\
\hline
\end{tabular}

b.d. - brak danych

Źródło: opracowanie własne na podst.: GUS (od 2000a do 2008a) oraz GUS (od 2000b do 2008b).

w województwie kujawsko-pomorskim. Można zauważyć, iż udział pracujących w spółkach z kapitałem zagranicznym w całkowitej liczbie pracujących w województwie kujawsko-pomorskim zwiększa się (według danych na koniec 2006 roku wynosił 5,13\%, odpowiednio dla 1999 roku 3,61\%). Jest to rezultatem wzrostu liczby pracujących w spółkach z udziałem kapitału zagranicznego, co wynika z kolei ze zwiększającej się liczby spółek.

Porównanie liczby pracujących w podmiotach z kapitałem zagranicznym z liczbą pracujących w przedsiębiorstwach bez kapitału zagranicznego w województwie kujawsko-pomorskim przedstawiono w tabeli 2. Zgodnie z danymi w niej zaprezentowanymi liczba pracujących w analizowanych podmiotach w 2007 roku wzrosła. W największym stopniu nastąpiło to w przypadku podmiotów z kapitałem zagranicznym, o 19\% w stosunku do roku poprzedniego. Zmiana ta była znacznie mniejsza w przypadku spółek z wyłącznie polskim kapitałem (3\%). W latach 2002-2007 przedsiębiorstwa bez kapitału zagranicznego zatrudniały średnio 84\% pracujących w województwie kujawsko-pomorskim. Udział przedsiębiorstw z kapitałem zagranicznym wynosił odpowiednio $16 \%$. Przewaga podmiotów z kapitałem zagranicznym uwidacznia się przy analizie danych dotyczących liczby pracujących przypadających na jedną spółkę. W województwie kujawsko-pomorskim w analizowanym okresie zatrudniały one średnio prawie dwukrotnie więcej pracowników niż spółki z wyłącznie polskim kapitałem. 


\section{WYDATKI INWESTYCYJNE W PRZEDSIĘBIORSTWACH W WOJEWÓDZTWIE KUJAWSKO-POMORSKIM}

Zgodnie z metodologią przyjętą przez polskie urzędy statystyczne „wydatki na pozyskanie aktywów trwałych to nakłady poniesione na wartości niematerialne i prawne, rzeczowe aktywa trwałe, należności długoterminowe, inwestycje długoterminowe, długoterminowe rozliczenia międzyokresowe” (GUS, 2007a). Rzeczowe aktywa trwałe to: środki trwałe, środki trwałe w budowie oraz zaliczki na środki trwałe w budowie (GUS, 2007b). „Nakłady na środki trwałe są to poniesione w okresie sprawozdawczym nakłady na nabycie (w tym również zakup środków trwałych niewymagających montażu lub instalacji) bądź wytworzenie dla własnych potrzeb środków trwałych, nakłady na środki trwałe w budowie (niezakończone, tj. na przyszłe środki trwałe), na ulepszenia własnych środków trwałych, na ulepszenia w obcych środkach trwałych oraz inne nakłady związane z budową środka trwałego - wraz z kosztami ponoszonymi przy ich nabyciu, tj. kosztami transportu, załadunku, ubezpieczenia w drodze, ceł itp." (GUS, 2007b). Wydatki na nowe środki trwałe obejmują nakłady poniesione na budowę lub (i) zakup środków trwałych, nakłady na wytworzenie środków trwałych we własnym zakresie, koszty dostosowania środka trwałego do użytkowania oraz nakłady na ulepszenie (przebudowę, rozbudowę, rekonstrukcję i modernizację) środków trwałych, w tym również na ulepszenie obcych środków trwałych (GUS, 2007a).

W województwie kujawsko-pomorskim w 2007 roku 61\% spółek z kapitałem zagranicznym poniosło wydatki inwestycyjne w wysokości 1504,3 miliona zł. Przedsiębiorstwa z kapitałem zagranicznym ponoszące wydatki inwestycyjne przeznaczają je w większości na pozyskanie nowych środków trwałych. W 2007 roku przeznaczyły na ten cel 89\% wydatków ogółem (GUS, 2008a). Dane prezentujące wartość wydatków inwestycyjnych przedsiębiorstw w województwie kujawsko-pomorskim zestawiono w tabeli 3.

Na podstawie danych w niej zawartych można stwierdzić, iż wydatki inwestycyjne spółek z wyłącznie polskim kapitałem znacznie przewyższały wydatki inwestycyjne przedsiębiorstw z kapitałem zagranicznym. Średnio wydatki inwestycyjne przedsiębiorstw bez kapitału zagranicznego w analizowanym okresie wynosiły 1665 mln zł, co stanowiło średnio 71\% wydatków podmiotów ogółem w województwie kujawsko-pomorskim. Wydatki przedsiębiorstw z kapitałem zagranicznym w latach 1999-2007 osiągały średnio 705 mln zł, a ich średni udział w wydatkach podmiotów ogółem dochodził do $29 \%$.

Na korzyść przedsiębiorstw z kapitałem zagranicznym kształtowały się wydatki inwestycyjne przypadające na jedno przedsiębiorstwo lub jednego 
Tabela 3. Wydatki inwestycyjne przedsiębiorstw z kapitałem zagranicznym i przedsiębiorstw bez kapitału zagranicznego w województwie kujawsko-pomorskim (lata 1999-2007, podmioty o liczbie pracujących 10 i więcej osób)

\begin{tabular}{|c|c|c|c|c|c|c|c|c|c|}
\hline \multirow{3}{*}{ Przedsiębiorstwa } & \multicolumn{9}{|c|}{ Lata } \\
\hline & 1999 & 2000 & 2001 & 2002 & 2003 & 2004 & 2005 & 2006 & 2007 \\
\hline & \multicolumn{9}{|c|}{ Wydatki inwestycyjne (w mln zł) } \\
\hline Z kapitałem zagranicznym & 542 & 471 & 733 & 533 & 615 & 530 & 708 & 710 & 1504 \\
\hline Bez kapitału zagranicznego & 1641 & 1654 & 1475 & 1391 & 1042 & 1641 & 1883 & 1939 & 2316 \\
\hline \multirow[t]{2}{*}{ Ogółem } & 2183 & 2125 & 2207 & 1924 & 1658 & 2170 & 2590 & 2649 & 3820 \\
\hline & \multicolumn{9}{|c|}{ Udział wydatków inwestycyjnych w wydatkach przedsiębiorstw ogółem (\%) } \\
\hline Z kapitałem zagranicznym & 24,8 & 22,2 & 33,2 & 27,7 & 37,1 & 24,4 & 27,3 & 26,8 & 39,4 \\
\hline \multirow[t]{2}{*}{ Bez kapitału zagranicznego } & 75,2 & 77,8 & 66,8 & 72,3 & 62,9 & 75,6 & 72,7 & 73,2 & 60,6 \\
\hline & \multicolumn{9}{|c|}{ Wydatki inwestycyjne przypadające na jedno przedsiębiorstwo (w mln zł) ${ }^{*}$} \\
\hline Z kapitałem zagranicznym & 2,7 & 2,2 & 3,5 & 2,5 & 2,9 & 2,4 & 2,9 & 2,9 & 5,7 \\
\hline Bez kapitału zagranicznego & - & - & - & 0,7 & 0,5 & 0,8 & 0,9 & 0,9 & 1,0 \\
\hline \multirow[t]{2}{*}{ Ogółem } & - & - & - & 0,8 & 0,7 & 0,9 & 1,1 & 1,1 & 1,5 \\
\hline & \multicolumn{9}{|c|}{$\begin{array}{l}\text { Wydatki inwestycyjne przypadające na jedno przedsiębiorstwo je ponoszące } \\
\qquad(\text { w mln zł) }\end{array}$} \\
\hline \multirow[t]{2}{*}{ Z kapitałem zagranicznym } & 3,0 & 2,4 & 3,9 & 2,9 & 3,2 & 2,6 & 3,2 & 3,1 & 6,1 \\
\hline & \multicolumn{9}{|c|}{ Wydatki inwestycyjne przypadające na jednego zatrudnionego (w tys. zł) ${ }^{*}$} \\
\hline Z kapitałem zagranicznym & 19,7 & 16,6 & 25,4 & 17,9 & 22,6 & 17,4 & 22,8 & 21,2 & 37,8 \\
\hline Bez kapitału zagranicznego & - & - & - & 8,3 & 6,0 & 9,6 & 11,3 & 11,0 & 12,8 \\
\hline Ogółem & - & - & - & 9,8 & 8,3 & 10,8 & 13,1 & 12,6 & 17,3 \\
\hline
\end{tabular}

* Dane odnoszą się do spółek z kapitałem zagranicznym, z tylko polskim kapitałem i do spółek ogółem w województwie kujawsko-pomorskim, nie odnoszą się wyłącznie do spółek ponoszących wydatki inwestycyjne ze względu na brak dostępnych danych na ten temat o spółkach ogółem i spółkach z polskim kapitałem.

Źródło: opracowanie własne na podst.: GUS (od 2000a do 2008a) oraz GUS (od 2000b do 2008b).

zatrudnionego. Średnio na jedną spółkę z kapitałem zagranicznym w 2007 roku przypadało 5,7 miliona zł, wartość ta była znacznie wyższa w odniesieniu do podmiotów ponoszących wydatki inwestycyjne $(6,1)$. W przypadku spółek z wyłącznie polskim kapitałem i spółek ogółem średnia w 2007 roku wynosiła odpowiednio 1,0 i 1,5 miliona zł. Można stwierdzić, iż w przeliczeniu na jedną spółkę podmioty z kapitałem zagranicznym ponosiły większe wydatki inwestycyjne niż spółki z wyłącznie polskim kapitałem i spółki ogółem ulokowane w województwie kujawsko-pomorskim. Podobna zależność dotyczy wydatków inwestycyjnych przypadających na jednego zatrudnionego. Spółki z kapitałem zagranicznym wydawały 37,8 tysięcy zł, a podmioty z wyłącznie polskim kapitałem prawie trzykrotnie mniej (12,8 tysięcy zł). 


\section{WYNIKI FINANSOWE PRZEDSIĘBIORSTW W WOJEWÓDZTWIE KUJAWSKO-POMORSKIM}

Dokonując porównania przedsiębiorstw z kapitałem zagranicznym i bez kapitału zagranicznego w województwie kujawsko-pomorskim, warto przeanalizować również podstawowe wyniki finansowe osiaggane przez te podmioty, a więc między innymi przychody z całokształtu działalności, które obejmują przychody netto ze sprzedaży, pozostałe przychody operacyjne i przychody finansowe. Przychody netto ze sprzedaży to wytworzone i sprzedane przez jednostkę produkty (wyroby gotowe, półfabrykaty oraz usługi) w kraju i na eksport, a także opakowania, wyposażenie i usługi obce, jeżeli są one fakturowane odbiorcom łącznie z produktami. Przychody netto ze sprzedaży towarów i materiałów to nabyte w celu odsprzedaży w stanie nieprzetworzonym rzeczowe aktywa obrotowe oraz produkty wytworzone przez jednostkę, jeśli sprzedawane są one w sieci własnych sklepów obok towarów obcej produkcji. Koszty uzyskania przychodów z całokształtu działalności obejmują: koszt własny sprzedanych produktów, towarów i materiałów, pozostałe koszty operacyjne i koszty finansowe (GUS, 2007a). W niniejszym opracowaniu skoncentrowano się na analizie przychodów z całokształtu działalności, kosztów uzyskania przychodów z całokształtu działalności oraz zysku netto ze względu na dostępność tych danych w sprawozdaniach przygotowywanych przez GUS uwzględniających poszczególne województwa.

W 2007 roku wysokość przychodów z całokształtu działalności osiąganych przez podmioty z kapitałem zagranicznym wynosiła 19 911,6 miliona zł (o 37\% więcej niż w 2006 roku). Podobnie jak w skali całego kraju najwyższe przychody z całokształtu działalności w województwie kujawsko-pomorskim uzyskały podmioty z kapitałem zagranicznym z sekcji przetwórstwo przemysłowe. Koszty przychodów z całokształtu działalności osiagnęły wartość 19 120,5 miliona zł i również wzrosły w stosunku do roku poprzedniego o 41\%. Zysk brutto w wysokości 794,5 miliona zł wykazały 304 podmioty, co stanowiło 58\% wszystkich spółek z kapitałem zagranicznym w województwie kujawsko-pomorskim. Wynik finansowy netto wynosił w 2007 roku 601,4 miliona zł i wykazały go 303 przedsiębiorstwa, 58\% podmiotów z kapitałem zagranicznym (GUS, 2008a).

Porównanie wyników finansowych osiaganych przez podmioty z kapitałem zagranicznym do wyników finansowych przedsiębiorstw bez kapitału zagranicznego w województwie kujawsko-pomorskim zaprezentowano w tabelach 4,5 i 6. 


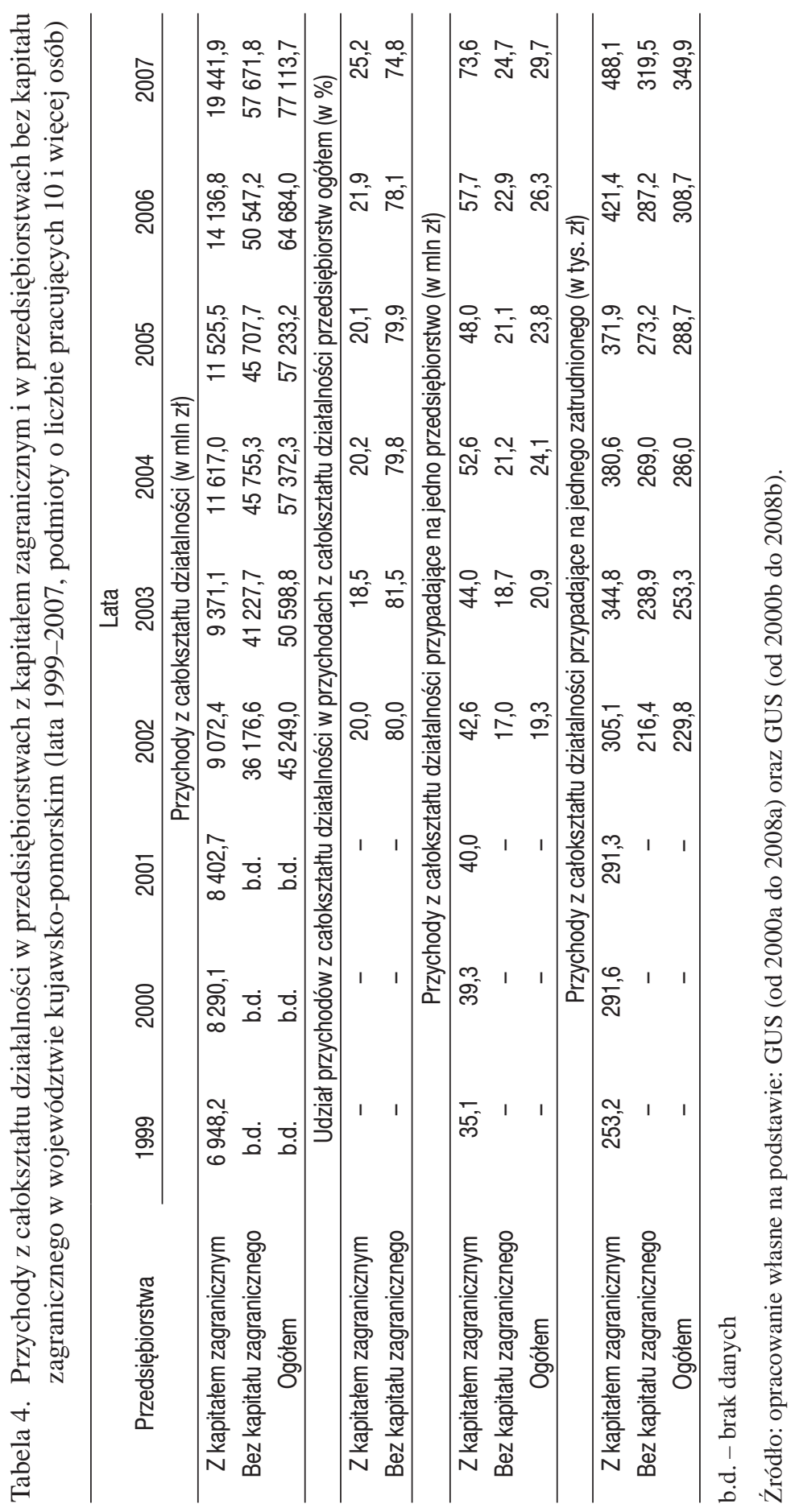




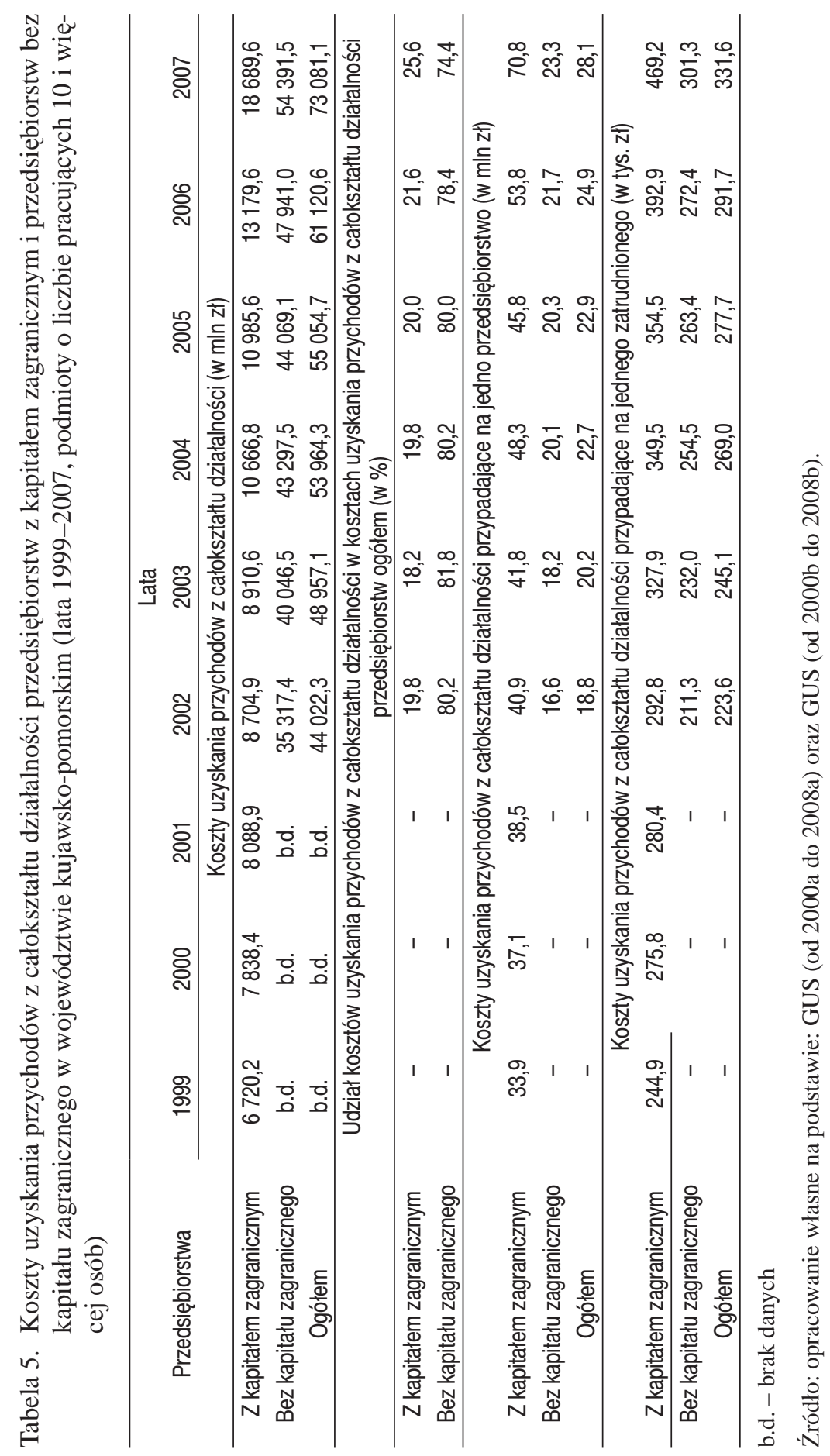




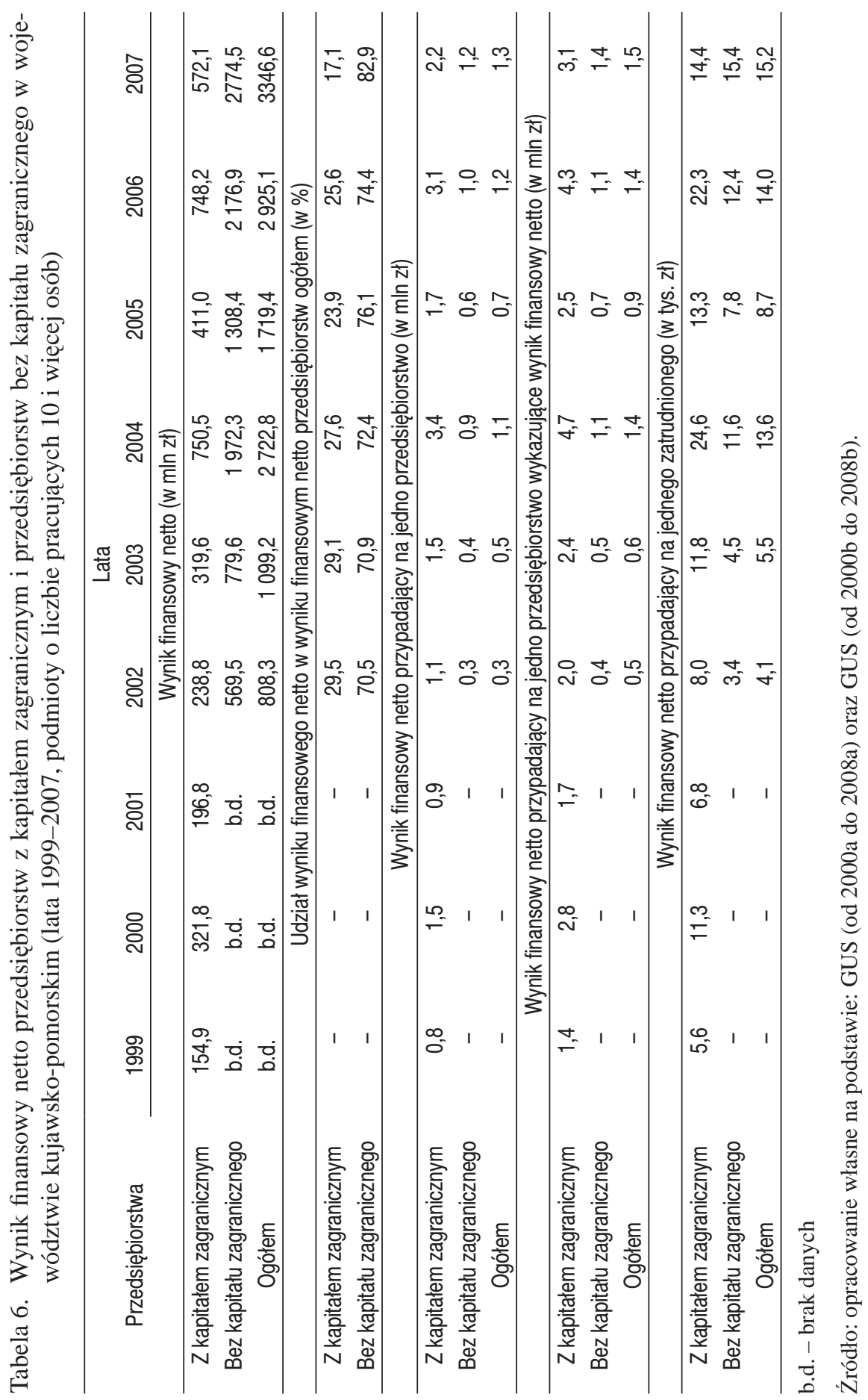


Na podstawie danych zaprezentowanych w tabeli 4 można stwierdzić, iż przedsiębiorstwa bez kapitału zagranicznego osiagały wyższe przychody z całokształtu działalności od przedsiębiorstw z kapitałem zagranicznym. W latach 2002-2007 wynosiły one średnio $46181 \mathrm{mln}$ zł, co stanowiło 79\% przychodów z całokształtu działalności ogółu podmiotów w województwie kujawsko-pomorskim. Przychody z całokształtu działalności przedsiębiorstw z kapitałem zagranicznym w latach 2002-2007 średnio dochodziły do 12527 mln, co stanowiło 21\% przychodów z całokształtu działalności ogółu podmiotów w województwie kujawsko-pomorskim. Przewaga przedsiębiorstw z kapitałem zagranicznym pod względem osiaganych przychodów z całokształtu działalności uwidacznia się w przeliczeniu danych na jedno przedsiębiorstwo i jednego zatrudnionego. Średnio na jedną spółkę z kapitałem zagranicznym w 2007 roku przypadało 73,6 miliona zł przychodów z całokształtu działalności, co stanowiło 3 razy więcej niż w przypadku spółek z wyłącznie polskim kapitałem. W przeliczeniu na jednego zatrudnionego spółki z kapitałem zagranicznym wykazywały 488,1 miliona zł przychodów, to jest 1,5 razy więcej niż spółki z wyłącznie polskim kapitałem. Można stwierdzić, iż w całym analizowanym okresie podmioty z kapitałem zagranicznym miały wyraźną przewagę nad spółkami z wyłącznie polskim kapitałem pod względem osiaganych przychodów z całokształtu działalności w przeliczeniu na jednego zatrudnionego. Charakteryzowała je również wyższa wydajność pracy mierzona wartością przychodów na jednego zatrudnionego.

Wyższe przychody z całokształtu działalności okupione były odpowiednio wyższymi kosztami, na co wskazują dane zaprezentowane w tabeli 5. Na podstawie danych zaprezentowanych w tabeli 6 można stwierdzić, iż przedsiębiorstwa bez kapitału zagranicznego osiagały wyższy wynik finansowy netto od przedsiębiorstw z kapitałem zagranicznym. W latach 2002-2007 wynosił on średnio 1597 mln zł, co stanowiło 75\% zysku netto ogółu podmiotów w województwie kujawsko-pomorskim. Wynik finansowy netto przedsiębiorstw z kapitałem zagranicznym w latach 2002-2007 średnio dochodził do $507 \mathrm{mln}$, co stanowiło 25\% zysku netto ogółu podmiotów w województwie kujawsko-pomorskim. Przewaga przedsiębiorstw z kapitałem zagranicznym pod względem osiąganego wyniku finansowego netto uwidacznia się w przeliczeniu danych na jedno przedsiębiorstwo i jednego zatrudnionego. Podmioty z kapitałem zagranicznym w 2007 r. uzyskały 1,8 razy wyższe wyniki finansowe netto przypadające na jedno przedsiębiorstwo od spółek z wyłącznie polskim kapitałem. Odnośnie do przedsiębiorstw, które wykazywały wynik finansowy netto, przewaga podmiotów z kapitałem zagranicznym była jeszcze bardziej imponująca, gdyż osiągnęły ponad 2,3 razy wyższy zysk netto przypadający na jedno przedsiębiorstwo. Zgodnie z danymi zaprezentowanymi w tabeli 6, w całym analizowanym okresie podmioty z kapitałem zagranicznym wypracowywały wyższy wynik finansowy 
netto przypadający na jedno przedsiębiorstwo. Na koniec 2007 roku jeden zatrudniony w przedsiębiorstwach bez kapitału zagranicznego przyczynił się do 1,1 razy wyższego wyniku finansowego netto niż w spółkach z kapitałem zagranicznym. Można domniemywać, iż przyczyną niewielkiej przewagi przedsiębiorstw z wyłącznie polskim kapitałem pod względem osiągniętego wyniku finansowego netto $\mathrm{w}$ przeliczeniu na jednego zatrudnionego był gwałtowny (aż $19 \%$ ) wzrost zatrudnionych w podmiotach $\mathrm{z}$ kapitałem zagranicznym. W latach 2002-2006 przedsiębiorstwa z kapitałem zagranicznym osiągały średnio dwukrotnie wyższy wynik finansowy netto w przeliczeniu na jednego zatrudnionego od przedsiębiorstw bez kapitału zagranicznego.

\section{PODSUMOWANIE}

Porównanie przedsiębiorstw z kapitałem zagranicznym i bez kapitału zagranicznego w latach 1999-2007 w województwie kujawsko-pomorskim ze względu na zasoby kapitałowe, zatrudnienie, nakłady inwestycyjne oraz osiagane wyniki finansowe wypada na korzyść przedsiębiorstw z wyłącznie polskim kapitałem. Przedsiębiorstwa bez kapitału zagranicznego o liczbie pracujących 10 i więcej osób na koniec 2007 roku spośród wszystkich przedsiębiorstw w województwie kujawsko-pomorskim o liczbie pracujących 10 i więcej osób skupiały $90 \%$ kapitału podstawowego, zatrudniały 82\% osób, ich udział w wydatkach ogółem na pozyskanie aktywów trwałych wynosił 61\%, udział w przychodach z całokształtu działalności ogółem osiągał 75\%, a udział w wyniku finansowym netto ogółem dochodził do 83\%. Osiagana przewaga wynikała z większej liczby przedsiębiorstw z wyłącznie polskim kapitałem, których udział w ogólnej liczbie przedsiębiorstw w województwie kujawsko-pomorskim na koniec 2007 roku stanowił 90\%.

Znaczenie podmiotów z kapitałem zagranicznym dla gospodarki województwa kujawsko-pomorskiego uwidacznia się, gdy zebrane dane porównamy z wynikami osiąganymi przez przedsiębiorstwa z wyłącznie polskim kapitałem w przeliczeniu na jedno przedsiębiorstwo i jednego zatrudnionego. Przedsiębiorstwa z kapitałem zagranicznym zatrudniały w przeliczeniu na jedną spółkę średnio prawie dwukrotnie więcej pracowników, dominowały pod względem wartości kapitału podstawowego i ponoszonych wydatków inwestycyjnych w przeliczeniu na jedną spółkę i na jednego zatrudnionego. Podmioty z kapitałem zagranicznym miały wyraźną przewagę nad spółkami z wyłącznie polskim kapitałem pod względem osiąganych przychodów z całokształtu działalności i uzyskiwanego zysku netto przypadających na jedną spółkę. Charakteryzowała je wyższa wydajność pracy mierzona wartością przychodów na jednego zatrudnionego. 
Jeden zatrudniony w tych podmiotach wypracowywał wyższy wynik finansowy netto (z wyjątkiem 2007 roku, w którym zaobserwowano niewielką przewage przedsiębiorstw z wyłącznie polskim kapitałem). Łączyło się to również z odpowiednio wyższymi kosztami. Można zatem domniemywać, iż spółki z kapitałem zagranicznym prowadzą bardziej efektywną politykę zatrudnienia. Działają w oparciu o być może lepiej zarządzane, opłacane, doświadczone i charakteryzujące się większą wiedzą zasoby ludzkie. Pozwala to przypuszczać, iż sukcesywna przewaga pod tym względem nad spółkami z wyłącznie polskim kapitałem czyni te przedsiębiorstwa ważnymi i pożądanymi dla gospodarki województwa kujawsko-pomorskiego, mimo ich obserwowanego niewielkiego udziału w ogólnej liczbie spółek.

\section{LITERATURA}

GUS (2000a), Działalność gospodarcza spótek z udziatem kapitału zagranicznego w 1999 roku, Warszawa.

GUS (2000b), Bilansowe wyniki fi nanøwe podmiotów gospodarczych w 1999 r., Warszawa.

GUS (2001a), Działalność gospodarcza spótek z udziałem kapitału zagranicznego w 2000 roku, Warszawa.

GUS (2001b), Bilansowe wyniki fi nanøwe podmiotów gospodarczych w 2000 r., Warszawa.

GUS (2002a), Działalność gospodarcza spótek z udziatem kapitału zagranicznego w 2001 roku, Warszawa.

GUS (2002b), Bilansowe wyniki fi nanøwe podmiotów gospodarczych w 2001 r., Warszawa.

GUS (2003a), Działalność gospodarcza spótek z udziałem kapitału zagranicznego w 2002 roku, Warszawa.

GUS (2003b), Bilansowe wyniki fi nanøwe podmiotów gospodarczych w 2002 r., Warszawa.

GUS (2004a), Działalność gospodarcza spótek z udziałem kapitału zagranicznego w 2003 roku, Warszawa.

GUS (2004b), Bilansowe wyniki fi nanøwe podmiotów gospodarczych w 2003 r., Warszawa.

GUS (2005a), Działalność gospodarcza spótek z udziałem kapitału zagranicznego w 2004 roku, Warszawa.

GUS (2005b), Bilansowe wyniki fi nanøwe podmiotów gospodarczych w 2004 r., Warszawa.

GUS (2006a), Działalność gospodarcza podmiotów z kapitałem zagranicznym w 2005 roku, Warszawa. 
GUS (2006b), Bilansowe wyniki fi nanøwe podmiotów gospodarczych w 2005 r., Warszawa.

GUS (2007a), Działalność gospodarcza podmiotów z kapitałem zagranicznym w 2006 roku, Warszawa.

GUS (2007b), Bilansowe wyniki fi nanowe podmiotów gospodarczych w 2006 r., Warszawa.

GUS (2008a), Działalność gospodarcza podmiotów z kapitałem zagranicznym w 2007 roku, Warszawa.

GUS (2008b), Bilansowe wyniki fi nanowe podmiotów gospodarczych w 2007 r., Warszawa.

Studzińska K., Szóstek A. (2005), Bezpośrednie inwestycje zagraniczne w województwie kujawsko-pomorskim na tle kraju, [w:] Karaszewski W. (red.), Bezpośrednie inwestycje zagraniczne w województwie kujawsko-pomorskim, UMK, Toruń.

US w Bydgoszczy (2008), Rocznik statystyczny województwa kujawsko-pomorskiego 2008, Bydgoszcz, http://www.stat.gov.pl (15.06.2009).

\section{COMPANIES WITH FOREIGN CAPITAL AGAINST COMPANIES WITHOUT FOREIGN CAPITAL IN KUJAWSKO-POMORSKIE VOIVODSHIP}

A bstract. This article is a trial of taking share in discussion about the importance of foreign capital for the economy of Kujawsko-Pomorskie voivodship through the presentation of companies with foreign capital against companies without foreign capital. The aim of this paper is to compare the companies with foreign capital and companies without foreign capital from Kujawsko-Pomorskie voivodship with regard to: capital resources, employment, investment outlays and financial results.

K e y w o r d s : region aspects, Kujawsko-Pomorskie voivodship, companies with foreign capital, capital resources, employment, investment outlays, financial results. 